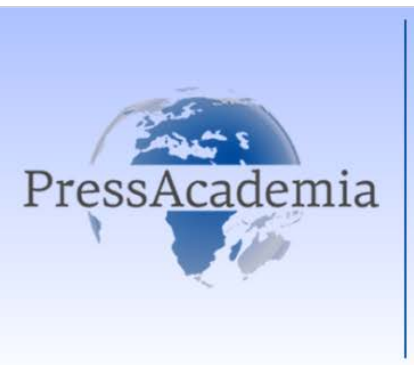

Press Academía

Procedía

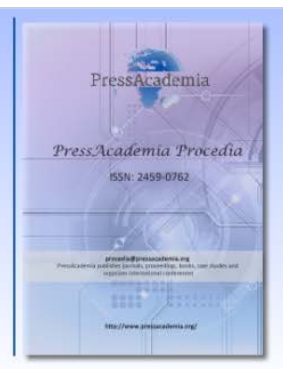

Global Business Research Congress (GBRC), May 26-27, 2016, Istanbul, Turkey.

\title{
FEMALE GENDER AND ENTREPRENEURSHIP
}

\section{DOI: 10.17261/Pressacademia.2016118639}

\author{
Sureyya Gumussoy ${ }^{1}$, Elif Aktekin, Gulseren Keskin \\ Ege Üniversitesi. sureyya.s@hotmail.com \\ Ege Üniversitesi. elif_aktekin@hotmail.com \\ Ege Üniversitesi. unalgulseren@hotmail.com
}

\begin{abstract}
The increasing number of women entrepreneurs is an important indicator of development socially. This study will examine the effects of having a female gender to the entrepreneurship. The databases in the social sciences and health sciences scanned, the results of research has compiled. Women live some problems because of being a woman in the entrepreneurial process. Some problems such as role conflict, insecurity, sexual expectations, experiences failure, the lack of information society that values and pressure on women, expectations of failure, difficulty in finding partners, housework and child care, blocking competitors, legal and bureaucratic obstacles, the difficulty of finding capital, prevent the entry of women into working life. Contributing to the economy in order to improve both social and economic development of our country to increase the number of women entrepreneurs, to that provided at the obstacles they face because they are women, and women are required to eliminate the difficulties.
\end{abstract}

Keywords: women entrepreneurs, Entrepreneurship, female gender

JEL Codes: M12, M1

\section{KADIN CINSIYETI VE GIRIŞiMCILIK}

\section{ÖZET}

Kadın girişimci sayısının bir ülkede fazla olması, sosyal anlamda ileri olmanın önemli bir kanıtıdır. Bu çalışmada, kadın cinsiyetine sahip olmanın kadınların girişimcilikleri üzerine olan etkileri incelenecektir. Sosyal bilimler ve sağlık bilimleri alanlarında veri tabanları taranmış, araştırma sonuçları derlenmiştir. Kadınlar, genel olarak girişimcilerin karşılaştıkları sorunların yanı sıra bir de kadın olmaktan dolayı birtakım sorunlar yaşamaktadırlar. Rol çatışması, güvensizlik, cinsel beklentiler, tecrübe yetersizliği, bilgi eksikliği, toplumun kadınlar hakkındaki değer yargıları ve baskısı, başarısızlık beklentisi, ortak bulmada güçlük çekme, ev işi ve çocuk bakımı, rakiplerin engellemeleri, yasal ve bürokratik engeller, sermaye bulma güçlüğü gibi konular kadınların iş hayatına girmesinde engel teşkil etmektedir. Ülkemizin hem sosyal hem de ekonomik gelişimini artırmak amacıyla ekonomiye katkı sağlayan kadın girişimcilerin sayılarının arttırılması, bunun sağlanabilmesi için de kadınların kadın olmalarından dolayı karşılaştıkları engellerin ve zorlukların ortadan kaldırılması gerekmektedir.

Anahtar Kelimeler: kadın girişimciler, girişimcilik, kadın cinsiyeti JEL Kodları: M12, M13 


\section{GiRiş}

Girişimcilik kelimesi, 1755 yılında Fransız Richard Cantillon'un iktisadi değişkenlikler içerisinde kazanç elde etmek ve belirsizliği anlatmak için kullandığı, girişimci manasına gelen "entreprendre" teriminden köken almaktadır (Onay ve Çavuşoğlu, 2010). Girişimcilik yenilikleri yakalama, fırsatları değerlendirme ve tüm bunların hayata geçirilme sürecidir. Girişimci ise doğal kaynaklar olarak bilinen üretim faktörlerini, emeği, teknolojiyi ve sermayeyi en yeni teknik yöntem ve bilgilerle birleştiren, aynı zamanda mal veya hizmet imal eden kişi olarak tarif edilmektedir (URL 1).

Bir ülkede gelişen ve üretebilen ekonominin var olması için gerekli olan, risk alabilen işletmeciliğin ilerletici gücü gibi düşünülen ve girişimci özellikleri olan bireyler, yeni buluşlar yaparak ve yeni işler kurarak ekonomik büyümeye yardımcı olurlar (Lundstrom and Stevenson, 2005). Eskiden kadınların toplumdaki statüsü açıkça el işi veya ev işi yapmak ile sınırlanmış iken Sanayi Devrimi'nden sonra günümüze kadar görev tanımlarında anlamlı değişimler olmuş, kadınlar da önlerine çıkan bazı zorluklara rağmen artık çalışma yaşamında aktif bir şekilde faaliyet göstermeye başlamışlardır. Bu çalışmada, kadın cinsiyetine sahip olmanın kadınların girişimcilikleri üzerine olan etkileri incelenecektir.

\section{LITERATÜR TARAMASI}

Çalışan kadınları koruyan ve destekleyen hukuki düzenlemelerin artması, eğitim fırsatlarının yaratılması, yaşanılan geçim sıkıntısı ve ekonomik zorluklar, boşanma oranlarının artması, kadınların çalışması konusunda toplumların tutumlarında olumlu yönde değişikliklerin olması, çocukların bakımları ve başka hizmetlerdeki iyileştirmeler sonucunda kadınların işgücüne katılımları artmış, çalışan eşlerin sayısında yükselme olmuş ve ailesinin maddi ihtiyaçlarını tek başına karşılayan annelere toplumda daha fazla rastlanmaya başlanmıştır bu sebeple girişimcilik konusu, toplumda erkeklerin olduğu kadar kadınların da ilgi odağı haline gelmiştir (Soysal, 2010).

Ülkemizde kadın girişimcilerle ilgili yapılan çalışmalar neticesinde kadının rolleri konusunda toplumun kalıplaşmış düşüncelerinin olması, kadınların girişimcilik konusunda eğitim almamış olmaları, ailelerinin tepkisi, iş yüklerinin çok olması, finansal destek bulma konusunda zorluk yaşamaları, kadınların güven oluşturabilmek için erkeklerden daha fazla uğraşmak zorunda kalması gibi bazı ortak sorunlar ortaya çıkmıştır. (Can, 2007). Cici ve Tekin'in Konya'da kadınların girişimcilik yolunda karşılaştıkları sorunların öz girişimcilik yetenekleri üzerindeki etkisini inceledikleri çalışmalarında; araştırmaya katılan kadın girişimcilerin karşılaştıkları sorunları sosyal destek eksikliği, yakın çevrelerinden örnek rol modeller görmemeleri, kadın girişimcileri destekleyici yasal düzenleme eksikliği ve vergi mevzuatında gerekli desteklerin sağlanmaması, kadın olmanın duygusal kararlar verebilmeye neden olabilmesi sebebiyle erkek çalışanları yönlendirmedeki zorluklar, devletin kadın girişimcilere finansal destek konusundaki eksiklikleri olarak belirlemişlerdir (Cici, 2013 ).

Çelik ve Özdevecioğlu, Nevşehir ilinde kadın girişimcilerin karşılaştıkları sorunlara ilişkin yaptıkları çalışmada, girişimcilikte kadın olmanın doğurduğu sorunları, güvensizlik, rol çatışması, ticari tecrübe eksikliği, cinsel beklentiler, toplumun baskısı, başarısız olma beklentisi, ortak bulma konusunda güçlük çekme olarak saptamışlardır (Çelik ve Özdevecioğlu, 2001). Sayın'ın, Aydın ilindeki kadın girişimcilerle yaptığı çalışmada sosyal ve kültürel çevrenin bakış açısının, kadınların mesleki eğitim almamalarının, Türkiye'deki siyasi yapılanmanın erkek egemen olmasının kadın girişimcileri olumsuz olarak etkilediğini belirlenmiştir (Sayın, 2011). Soysal, Kahramanmaraş ilindeki kadın girişimcilerle yaptığı çalışmada; kadın girişimcilerin girişimcilik etkinliklerinde karşılaştığı güçlükleri kadınlar konusunda toplumun düşünceleri, bilgi azlığı, finansal düzenin olmaması, bürokratik ve yasal engeller, pazar koşullarındaki değer yargıları, rakiplerin engellemesi olarak saptamıştır (Soysal, 2010). Erdun ve Yıldırım, Zonguldak'taki kadın girişimciler konusunda yaptıkları araştırmalarında; çalışmaya alınan kadın girişimcilerin, işletmelerini kurarken baş etmek zorunda oldukları zorlukları incelemişler; bu bağlamda pazarda tanınmıyor olmak, finansman konusunda yetersizlik, uygun alan seçiminin güçlüğü, deneyim sorunu, bürokratik zorluklar, işte başarısız olunacağı düşüncesi, ailedeki sorumluluklar nedeniyle vakit azlığı ve ailedeki büyükten izin alamama gibi sorunlarla karşılaşıldığını tespit etmişlerdir (Erdun, 2011). 


\section{VERI VE YÖNTEM}

Sosyal bilimler, sağlık bilimleri alanlarındaki veri tabanları ve Google Akademik'te kadın girişimciler, girişimcilik, kadın cinsiyeti gibi anahtar kelimeler kullanılarak sözkonusu makaleler taranmış ve uygun bulunan araştırma sonuçları derlenmiştir.

\section{BULGULAR VE TARTIŞMA}

Cinsiyet, bireyin sahip olduğu cinsiyete bağlı olarak gösterdiği fizyolojik, biyolojik ve genetik vasıflarıdır. Toplumsal cinsiyet ise, kadının ve erkeğin biyolojik farklılıklardan dolayı değil toplum tarafından belirlenen rol ve sorumluluklarıdır. Başka bir ifadeyle toplumun erkek ve kadın olarak bireyi nasıl gördügüu, nasıl algıladığı, nasıl düşündüğü ve nasıl davranmasını beklediği ile ilgili bir kavramdır (Akın ve Demirel, 2003). Kadın girişimciler, bütün girişimcilerin çözmek zorunda oldukları problemlerin yanında aynı zamanda kadın cinsiyetine sahip olmaları nedeniyle de bazı sorunlar yaşamaktadırlar (Soysal, 2010-2011). Türk toplumunda, genel olarak hâkim olan düşünce; kadın için çalışacağı en uygun yerin evi ve yapacağı en müsait işin ise kendi çocuklarının bakımı ve kendi evi ile ilgili işleri yapmaktır. Bu nedenle çalışmak isteyen kadınlar için evli ise eşlerini değilse ailelerini ikna etmek zorunluluğu oluşmaktadır. Bir başka deyişle, özellikle gelir düzeyi düşük olan ailelerde yaşayan kadınlar aile büyüklerinin veya eşlerinin iznini almadan çalışma hayatına girmekte güçlük çekmektedirler (Bedük, 2005).

Toplumda duygusal, insancıl ve pasif olma, sürekli rasyonalist olamama, çok yönlü ve etraflıca düşünememe gibi kadınlara atfedilen bazı özelliklerin olduğu ve aynı zamanda akılcı ve serinkanlı olma, stratejik düşünme yeteneğine sahip olma, karar verirken örgütün amaçlarını dikkate alma böylece kaynakları en verimli şekilde kullanarak mal veya hizmet üretme faaliyeti konusundaki yeteneklerin yalnızca erkeklerde bulunduğu gibi bir takım hatalı düşünce ve inançlar bulunmaktadır (Bedük, 2005). Kız ve erkek çocukların sosyalleşme süreçlerinin farklı olması sebebiyle toplumsal cinsiyet rolleri ile uyumlu mesleklerde faaliyet göstermeleri beklenmektedir bu nedenle çalışma hayatında erkeğin ve kadının ayrı ayrı yapması beklenen meslekler ortaya çıkmaktadır (Erdun, 2011). Bu yüzden kadınlar, toplumun belirlemiş olduğu cinsiyet kalıpları kapsamında eğitim almaları sebebiyle daha çok sağlık, eğitim, tekstil, gıda gibi hizmet sektörü alanlarında faaliyet göstermektedirler (Çakıcı, 2004). Toplum tarafından kadınların kadın cinsiyetine uygun bulunan aynı zamanda annelik ve kadınlık rollerinin türevleri olan öğretmenlik, doktorluk, hemşirelik, sekreterlik gibi mesleklerde, anne ve eş rollerini ihmal etmeden çalışması uygun görülmektedir (Erdun, 2011). Türkiye'de kadının ücretli olarak çalışabilmesi ancak, eş ve anne rolünü yerine getirdiği takdirde kabul görmekte ve meşru sayılmaktadır. Bu rollerinden kaynaklanan sorumluluklar kadına önemli ölçüde zaman ve hareket darlığı getirmekte ve formel sektörde gelir getirici faaliyetlerde bulunma kapasitesini zorlamaktadır (T.C. Başbakanlık Kadının Statüsü ve Sorunları Genel Müdürlüğü, 2000).

Kadın girişimcilerin önündeki en büyük engellerden bir tanesi de, maddi güçlerinin olmaması sebebiyle iş kurmak için gerekli sermayelerinin bulunmamasıdır. Kadınlar, gayrimenkullerin çoğunlukla ailedeki erkeklerin üzerine olması ve dolayısıyla üzerlerinde teminat gösterebilecek mal varlıklarının bulunmaması sebebiyle kredi de alamamaktadırlar. (Güleç, 2011). Kadınların iş hayatında yeterli tecrübelerinin olmaması, çıraklık ve mesleki eğitim konusunda erkekler kadar şanslı olmamaları, erkek girişimciler kadar uzun süredir iş yaşamında bulunmamaları, toplumun girişimcilik kavramını erkeklere yakıştırması gibi durumlar kadınları bildiği işleri yapmaya yönlendirmekle birlikte beceri kazanmalarını engellemekte ya da geciktirmektedir (Keskin, 2014).

\section{SONUÇ}

Kadın girişimci sayısının bir ülkede fazla olması, sosyal anlamda ileri olmanın önemli bir kanıtıdır. Ülkemizin hem sosyal hem de ekonomik gelişimini artırmak amacıyla ekonomiye katkı sağlayan kadın girişimcilerin sayılarının arttırılması, bunun sağlanabilmesi için de kadınların kadın olmalarından dolayı karşılaştıkları engellerin ve zorlukların ortadan kaldırılması gerekmektedir. 


\section{KAYNAKLAR}

Akın, A., Demirel, S. (2003), Toplumsal Cinsiyet Kavramı ve Sağlığa Etkileri. Cumhuriyet Üniversitesi Tıp Fakültesi Dergisi 25(4):73-82.

Bedük, A. (2005), Türkiye'de Çalışan Kadın ve Kadın Girişimciliği Elektronik Sosyal Bilimler Dergisi, 3(12):106-117.

Can, Y., Karataş, A. (2007), Yerel Ekonomilerde Kalkınmanın İtici Gücü Olarak Kadın Girişimcilerin Rolü Ve Mikro Finansman: Muğla i̇li Örneği. Selçuk Üniversitesi Karaman İ. İ. B. F. Dergisi Yerel Ekonomiler Özel Sayısı, 251-261.

Cici, E. N. (2013), Kadınların Girişimcilik Yolunda Karşılaştıkları Sorunların Öz Girişimcilik Yetenekleri Üzerindeki Etkisi: Konya i̇linde Bir Araştırma. Selçuk Üniversitesi Sosyal Bilimler Enstitüsü İ̧̧letme Anabilim Dalı Üretim Yönetimi ve Pazarlama Bilim Dalı Yüksek Lisans Tezi, (Danışman Prof. Dr. Mahmut Tekin).

Çakıcı, A. (2004), Kadın Girişimcilerin İşletme Fonksiyonlarındaki Etkisinin Belirlenmesine Yönelik Bir Araştırma. Yönetim Bilimleri Dergisi, ( $1: 3)$.

Çelik, C., Özdevecioğlu, M. (2001), Kadın Girişimcilerin Demografik Özellikleri ve Karşılaştıkları sorunlara İlişkin Nevşehir ïlinde Bir Araştırma. 1. Orta Anadolu Kongresi (Nevşehir): 487-498.

Erdun, Ş. (2011), Kadın Girişimcilerin Risk Alma Eğilimi ve Kendine Güven Özellikleri Üzerine Bir Çalışma: Zonguldak Örneği. Zonguldak Karaelmas Üniversitesi Sosyal Bilimler Enstitüsü İ̧̧letme Anabilim Dalı Yüksek Lisans Tezi, (Tez Danışmanı Yrd. Doç. Dr. Halil Yıldırım).

Güleç, S. (2011), Kadın Girişimciliği-Karaman Örneği. Karamanoğlu Mehmetbey Üniversitesi Sosyal Bilimler Enstitüsü, İşletme Ana Bilim Dalı Yüksek Lisans Tezi, (Tez Danışmanı Prof. Dr. H. Bahadır AKIN).

URL 1: http://www.fatih.edu.tr/ ahmetcaliskan/buyume-gelisme1/girisimcilik raporu.pdf Erişim Tarihi: 20.04.2016

Keskin, S. (2014), Türkiye’ de Kadın Girişimcilerin Durumu. Girişimcilik ve Kalkınma Dergisi, 9:1.

Kutanis, R.Ö. (2006), Girişimci Kadınlar, Değişim Yayınları, İstanbul.

Lundstrom, A., Stevenson, L.A. (2005), Entrepreneurship Policy Theory and Practice, Isen International Studies Press, Canada: 27

Onay, M., Çavuşoğlu, S. (2010), İşletmelerde Girişimcilik Özelliğini Etkileyen Faktörler: İç Girişimcilik. Yönetim ve Ekonomi, 17(1): 47-67.

Sayın, E. (2011), Kadın Girişimcilerin Sorunlarının Betimleyici Analizi, Organizasyon ve Yönetim Bilimleri Dergisi, 3(1) ISSN: 1309-8039.

Soysal, A. (2010), Türkiye'de Kadın Girişimciler: Engeller ve Fırsatlar Bağlamında Bir Değerlendirme. Ankara Üniversitesi SBF Dergisi, 65(1):83-114

Soysal, A. (2010), Kadın Girişimcilerin Özellikleri, Karşılaştıkları Sorunlar ve İş Kuracak Kadınlara Öneriler: Kahramanmaraş illinde Bir Araştırma. Eskişehir Osmangazi Üniversitesi libf Dergisi, 5(1): 71-95.

T.C. Başbakanlık Kadının Statüsü ve Sorunları Genel Müdürlüğü (2000), Türkiye'de Kadınlara Ait Girişimlerin Desteklenmesi, Ankara, Aralık, s. 17. 